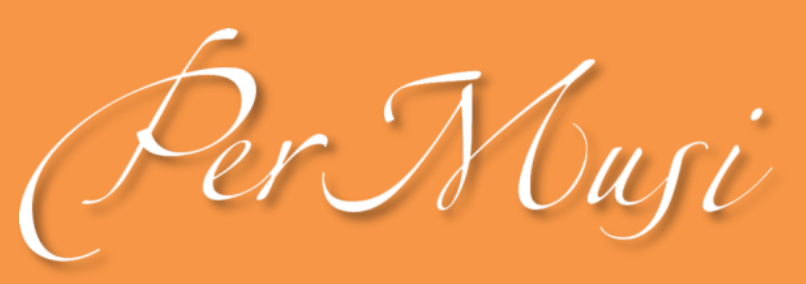

eISSN 2317-6377

\title{
Reflections on feminist collaborative initiatives in music in Brazil and their implications to the policies of resistance and creativity
}

\author{
Tânia Mello Neiva \\ Universidade Federal da Paraíba \\ taniamelloneiva@gmail.com \\ Isabel Porto Nogueira \\ Universidade Federal do Rio Grande do Sul \\ isabel. isabelnogueira@gmail.com \\ Camila Durães Zerbinatti \\ https://orcid.org/0000-0003-2449-9320 \\ Universidade Federal de Santa Catarina \\ camiladuze@gmail.com \\ SCIENTIFIC ARTICLE. \\ Submitted date: 10 Dec 2018. \\ Final approval date: 04 Apr 2019
}

Abstract: In this article we discuss two initiatives involving women, music and collaborative and creative work in Brazil as possibilities of breaking with and / or weakening hegemonic logics of knowledge production and ways of life / coexistence according to the political dimension of decolonial feminism. They are "Mostra XX" (XX Show) and Isabel Nogueira and Leandra Lambert duo. We propose a reflexive and critical look at our local context and possible creative and political outings of the traps that are imposed on us and that we also help to arm.

Keywords: Decolonial feminism; Mostra XX; Isabel Nogueira and Leandra Lambert duo, brazilian experimental music.

REFLEXÕES SOBRE AS INICIATIVAS COLABORATIVAS FEMINISTAS EM MÚSICA NO BRASIL E SUAS IMPLICAÇÕES EM AÇÕES DE RESISTÊNCIA E CRIATIVIDADE

Resumo: Neste artigo abordamos duas iniciativas envolvendo mulheres, música e trabalho colaborativo e criativo no Brasil como possibilidades de rompimento com e/ou enfraquecimento de lógicas hegemônicas de produção de conhecimento e modos de vida/coexistência de acordo com a dimensão política do feminismo decolonial. As iniciativas são a "Mostra XX" e o duo formado por Isabel Nogueira e Leandra Lambert. Propomos um olhar reflexivo e crítico sobre o nosso contexto local e possíveis respostas políticas às armadilhas que nos são impostas e que também ajudamos a armar.

Palavras-chave: Feminismo decolonial; Mostra XX; Duo Isabel Nogueira e Leandra Lambert, Música experimental brasileira. 


\section{Reflections on feminist collaborative initiatives in music in Brazil and their implications to the policies of resistance and creativity}

Tânia Mello Neiva, Universidade Federal da Paraíba, taniamelloneiva@gmail.com

Isabel Porto Nogueira, Universidade Federal do Rio Grande do Sul, isabel.isabelnogueira@gmail.com

Camila Durães Zerbinatti, Universidade Federal de Santa Catarina, camiladuze@gmail.com

\section{Introduction}

In this article we discuss two initiatives involving women, music and collaborative and creative work in Brazil as possibilities of breaking with and / or weakening hegemonic logics of knowledge production and ways of life / coexistence according to the political dimension of decolonial feminism. They are "Mostra XX" (XX Show) and Isabel Nogueira and Leandra Lambert duo. Our statements are the ones from Brazilian feminist white and non-white women (depending on the context), from different locations in the country, with an academic background in music - undergraduate and postgraduate. We ourselves are performers, researchers, composers and educators ${ }^{1}$.

\footnotetext{
${ }^{1}$ As stated by various feminist trends, especially those of intersectionality, post-colonial and decolonial trends, it is important to establish our "place of speech", for it is never neutral. Thus, we assume, at the same time, a political stance and risk of vices built in our context, allowing a true dialogue with the interlocutor male or female. This is to say that we can neither homogenize the group we are going to analyze nor assume a place of the "universal one" by comparing the analyzed situation, starting from the presupposition of oppression, which necessarily results in the silencing of the movements of resistance and the particularities of the group in question. It is what Chandra Mohanty (1984) criticizes in Western feminists who analyze women from the "third world" in the Zed Press publications "Women in the Third World. "In the author words: "What is problematical, then, about this kind of use of "women" as a group, as a stable category of analysis, is that it assumes an ahistorical, universal unity among women based on a generalized notion of their subordination. Instead of analytically demonstrating the production of women as socio-economic political groups in particular contexts, this move limits the definition of the subject to gender identity, completely by passing social class and ethnic identities. What characterizes women as a group is their gender (sociologically not necessarily biologically defined) over and above everything else, indicating a monolithic notion of sexual difference. Because women are thus constituted as a coherent group, sexual difference becomes coterminous with female subordination, and power is automatically defined in binary terms: people who have it (read: men), and people who do not (read: women). Men exploit, women are exploited. As suggested above, such simplistic formulations are both reductive and ineffectual in designing strategies to combat oppressions. All they do is to reinforce binary divisions between men and women. (Mohanty 1984, 344).
} 
Our formations, each of us within a specificity, could be understood as that of privileged people in the face of the current Brazilian reality. For example, according to IBGE (2013) and OECD (2015), in terms of schooling we represent approximately $0.5 \%$ of the Brazilian population, since the majority of the population do not finish high school and barely reach higher education. Our areas of action also reflect a privileged situation that of the arts. In Brazil, these areas, especially within the academy, are frequented and occupied by people with great purchasing power and cultural formation more aligned with European and North American traditions. In Brazil, we are also privileged people because we are considered ethnically and racially as white or non-black / non-indigenous people. Even if one of us positions herself as nonwhite, we know that none of us are seen in our local contexts as black or indigenous, and this also places us in a privileged position in relation to other women who suffer more severe social oppression than we normally do.

Thus, when we propose to speak of a perspective of rupture with colonizing and privileged models and schemes, we understand the limit of our discourses, which themselves come from privileged places in our local context. Still, we believe it is necessary to point out that this presentation is a reflexive academic proposal which does not intend to speak on behalf of any particular group.

We propose analytical views of initiatives that may represent ruptures in relation to very specific models and practices. We take mainly as a reference point that of a broken model; namely the musical knowledge approached in Brazilian conservatories and universities, which are based on North American and European repertoires from Germany, Austria, Italy, France, Russia, England, Spain and other countries. Although the models followed by our institutions are not exactly the same as the ones followed by those countries, the current discourse in Brazil is that such a model and its canonized repertoire as well as the way to approach them (usually in a solitary, competitive and demanding way) is our gateway to the world of music. In this way, we perceive that our institutions produce and reproduce discourses and practices of formation of a privileged class, supposedly based on European and North American cultures. These discourses and practices were not created and invented out of nowhere, they have a history that, according to the thinkers allied to the theories emerging from Global South, is closely related to the processes of American colonization.

Having said that, even if it is not our intention to be spokespeople for decolonial feminism, we believe we can establish an honest dialogue that can encourage reflection on the colonizing processes (internal and external) and the dangers of appropriation. Also, it must be said, many of the leaders of this feminist movement in Brazil, such as Ochy Curiel, Yuderkis Espinosa Miñoso and others, criticize academic decolonial feminist strands by arguing that decolonization should not be a theory devoid of practice and that decolonization is a daily struggle well beyond the walls of university.

\section{Cultural studies, colonialities and (de)colonialities}

Postcolonial theories and concepts of development, underdevelopment and developing world critics emerged in the 1970s in the field of cultural studies. The idea of development related to countries was proposed in 1949 by Harry Truman, president of the United States. In general terms, Truman proposed the use of these terms associated with notions of wealth and poverty. Wealth and poverty should be linked to established economic power, through productive capacity, exploitation of labor and nature. As such, countries around the world were classified as rich / developed and poor / underdeveloped. In the concept of development lies the idea that countries classified as underdeveloped or developing not only wish to be 
developed but should move to that end with the help of developed countries, mainly through financial loans and public policies.

However, as Mirian Lang (2016) points out, the perspective of a whole world of developed countries is unsustainable since wealth has been and is only possible through the exploitation of poor countries (underdeveloped / developing) both in terms of human and material resources. Beyond the logical question of the impossibility of generalized wealth, researchers and thinkers of the so-called underdeveloped or developing countries, which we call Global South ${ }^{2}$, began to question the very concepts of development / underdevelopment and wealth established by these rich countries themselves. Such a questioning proved even more necessary when it was realized that the model of economic development of rich countries did not translate into population happiness and well-being ${ }^{3}$. In this sense, for example, the work of caring which is exercised primarily by women is not valued because it is not seen as productive. Thus, not only are poor countries perceived as inferior, and therefore silenced in their own practices and dynamics, as are many women who carry even more strongly the marks of oppression.

At that time, feminist movements in Western Europe and the United States were in the 'Second Feminist Wave' effervescence, which began in the 1960s. During the Second Wave, marked by movements of deconstruction of the concepts of man and woman, sexes and sexuality denaturalization, sexual and identity liberation and others, it was possible to see more women occupying power positions in strategic institutions of knowledge production in universities and some government positions of these localities. The struggles for voting rights, studies and public life characteristic of the First Feminist Wave (late nineteenth and first decades of the twentieth century) bore fruit through women's presence in several public areas and work, which had previously and predominantly been associated with men and males. At the same time, as it had also been perceived and denounced inside the feminist movements of late nineteenth and early twentieth centuries, many of these conquests concerned a certain class of women, leaving many others women out. Black, Latin American and indigenous women from undeveloped localities in the world were not part of this group of women to whom the public space was addressed and whose struggle was recognized. Again, it was necessary to denounce attitudes, behaviors, discourses, racist, elitist, classist and exclusionary practices in the feminist movement itself. Thus, marginal feminisms (black, intersectionality, postcolonial, decolonial feminism) have criticized and questioned hegemonic feminisms, for reproducing what they have identified as one of the major problems and misunderstandings of societies - the assumption of the "universal one" and supposedly "universalizable / generalizable one", which is, in this case, man / male / white/ eurocentric. Yet hegemonic feminists reproduced such an error in not perceiving and being unable (or unwilling) to hear and notice women who did not share the same oppressions as them, whose problems were 'other'. Thus, the non-hegemonic feminisms that criticize a feminism whose subject was a specific, white, heterosexual and bourgeois woman who oppresses and silences other

\footnotetext{
${ }^{2}$ As a political stance that rejects the terms development, underdeveloped, developing, and also the Third World, we assume - supported by authors and writers like Chandra Mohanty, Gaytry Spivak, Ochy Curiel, Gloria Anzaldúa, Boaventura de Sousa Santos, Aníbal Quijano and others - the term Global South.

3 Mirian Lang (2016), quotes some studies proving that many countries considered as rich and / or developed are champions in the ranking of suicides and depressions like Norway, Denmark, Australia and the United States. It seems to be a direct relationship between this notion of wealth and development with "loneliness, existential anguish, depression, permanent stress that causes multiple physical and mental illnesses, including a lethal one; the instrumental human relations, the lack of coexistence, the time to share or even to enjoy things that one buys." (Lang 2016, 27).
} 
women require that their different contexts and struggle specificities exist, be listened to, named and respected. This explains the resurgence of Black feminism and Global South feminism.

At the end of the 1980s, the Peruvian political scientist Aníbal Quijano proposed the concept of Power Coloniality, which in the following decade was developed by the Modernity / Coloniality Group ${ }^{4}$ of which the researcher was a member. In the context of the Modernity / Coloniality Group, that concept was dismembered in two other categories: Coloniality of Knowledge and Coloniality of Being. Both concepts are the basis of the development of Maria Lugones' thought, the Argentine feminist philosopher and social critic. She developed in the 1990s the concept of Gender Coloniality, which will be fundamental to the birth of Decolonial Feminism in Latin America.

With the concept of Coloniality of Power, Quijano states that relations, values, beliefs and practices established by colonialism continue to be perpetuated even with the end of the colonial system and the beginning of Modernity. On the one hand, this concept denounces that colonial forms of domination remain through colonial and world-system cultures $^{5}$, as explained by Luciana Ballestrin, and, on the other hand, "it has an explanatory capacity that updates and temporalizes processes which supposedly would have been erased, assimilated or overcome by modernity" (Ballestrin 2013, 100). It means that mechanisms of domination established in colonization by the relationship between Europeans and Americans ${ }^{6}$ were and are used and naturalized both by the privileged and dominated people, with a focus on the colonization of the Americas, closely related to the capitalist system:

Coloniality is one of the constituent and specific elements of the world pattern of capitalist power. It is based on the imposition of a racial / ethnic classification of the world population as the foundation stone of that power pattern and operates in each of the planes, scopes and material and subjective dimensions of daily social existence and

\footnotetext{
${ }^{4}$ This group was formed in late 1990s by a group of Latin American intellectuals from several universities in the Americas. It was one of the great responsible for establishing the debate of the "decolonial turn" in social sciences, realizing that the tools used traditionally in the discipline reinforce stereotypes created by the image of subaltern social groups and developed social groups (Ballestrin 2013, 89).

${ }^{5}$ World System is a term proposed by social scientist Immanuel Wallerstein and used by Aníbal Quijano to elaborate his theory on coloniality and coloniality of power World System establishes that the economic, cultural and social capitalist relations that had its origin in Middle Age were extended to the rest of the world, creating a center, peripheries and semi peripheries of this world economic-social system. Aníbal Quijano has used and develop this concept for Modern / colonial system, in which he says that modern world was created from colonialism and this one created two Americas, one central and rich and the other marginal and poor (Hurtado 2017).

6 In "The coloniality of power: Eurocentrism and Latin America" (2005), Aníbal Quijano states that, as concepts, Europe and America were only possible from colonialism. When the Spaniards, Portuguese and English people "found" these lands, they characterized the peoples who lived there as inferior peoples and established racial differences, proclaiming themselves as developed, civilized and "human" in opposition to the peoples they encountered. The phenotypic difference was the main basis for establishing these categories. Thus, colonization postulated from the outset that there were white, educated, and human men (for they were Christians and had souls) and black and dark (reddish) beings who were savage and virtually without humanity (were not Christians, therefore, had no soul). Tania Navarro Swain (1996) demonstrates how the historical and ethnographic speeches made by European white men built the misogynistic, sexist and racist images of the Indians and especially the women in the Americas.
} 
social scale. It originates and globalizes from America itself. (Quijano 2000, 342 apud Barbosa and Maso, sd, p. 5) ${ }^{7}$

Following the same line of reasoning, Walter Mignolo, an Argentine semiologist, a member of the Modernity / Coloniality Group has continued Quijano's theory presenting the Coloniality of knowledge concept with Nelson Maldonado Torres who developed the Coloniality of being concept. They indicate coloniality mechanisms in people themselves and in the processes of knowledge production. The coloniality of being refers to the election of some groups as universal and to others as marginal, incomplete, immature (that is when people are considered as people at all), mainly stating racial and ethnic differences as determining components.

Similarly, there is the coloniality of knowledge, which indicates that the knowledge developed by these groups considered subaltern and inferior, are not worthy of being reproduced or known. Thus, stories, legends and beliefs of entire peoples and communities have been destroyed, forgotten and never heard in favor of a model considered unique. Eurocentrism is born. An example of this is our school curricula, which is built on the knowledge basis developed by Europeans and North Americans, from the United States. Here in Brazil, we study the History of Civilization, but this history (taken as universal) refers to the history of Western Europe and, after colonialism, also to the United States. We ignore Africa and Asia history and many others histories. We learn a little about our ancestors in the study of pre-Columbian civilizations ${ }^{9}$ but we know nothing about indigenous ethnic groups of our territory because they have been silenced since the Americas invention. Their lives, history and knowledge were not considered important for 'global' development. In the same way, the musical content that we learn in our institutional courses, like in

7 Free translation by the authors. The original follows: "La colonialidad es uno de los elementos constitutivos y específicos del patrón mundial de poder capitalista. Se funda en la imposición de una clasificación racial/étnica de la población del mundo como piedra angular de dicho patrón de poder y opera en cada uno de los planos, ámbitos y dimensiones, materiales y subjetivas, de la existência social cotidiana y a escala societal. Se origina y mundializa a partir de America." (Quijano, 2000: 342 apud Barbosa e Maso, sd, p.5, in http://eventos.ufgd.edu.br/enepex/anais/arquivos/435.pdf).

8 In the event of the Americas colonization natives who were found in the territory were not considered human, or at most, they were considered subhuman because they were not Christians and therefore there were doubts whether they had a soul. They were considered much more like domesticable animals, with some degree of intelligence that allowed them to be catechized, for example. From this conception of human being, associated with a specific, monotheistic, and also a type of locality in which they were located - an uncivilized place (Maldonado-Torres 2016, 85), were justified: slavery, decimation of cultures, customs, religions, arts, identities and others. As said by Boaventura de Sousa Santos (2009): "Based on their refined definitions of humanity and human dignity, humanists of fifteenth and sixteenth centuries came to the conclusion that savages were subhumans. The question was: Do the Indians have a soul? When Pope Paul III answered affirmatively in the bull Sublimis God of 1537, he did so by conceiving savage people's soul as an empty receptacle, an anima nullius, very similar to the land nullius, the concept of the legal void that justified invasion and occupation of indigenous territories. On the basis of these abyssal conceptions of epistemology and legality, the universality of the tension between regulation and emancipation, applied on this side of the line, does not contradict the tension between appropriation and violence applied on the other side of the line (Santos 2009, 29). (Our free translation)

${ }^{9}$ The pre-Columbian civilizations are civilizations that existed in the territory that we call America today before the Europeans arrival. 
conservatories, university and free courses in Brazil are also based on European and North American models.

Global Southern authors linked to the Modernity / Coloniality Group will argue that internal colonization is created and perpetuated by colonization which accentuates ethnic-racial and class differences. In other words, coloniality mechanisms - the choice of the "universal one" as central and referential and the classification of "everything else" as marginal, oppression based on race, ethnicity, geography and class resulting from the process of colonization - are experienced between nations and reproduced internally in countries, cities and localities. (Ballestrin 2013; Barbosa and Maso 2014). Concepts of coloniality, coloniality of power, being and knowledge form the basis of the decolonial concept and practice, commonly referred to as "decolonial turn", which uses them as a "new way of producing knowledge" (Mena 2016, 46), understanding knowledge in an extended way in which are considered both the subjective symbolic dimension and the objective practical dimension. Knowledge is, thus, defined by Maldonado-Torres (2016) as attitude and project.

It is in this context of decolonial theory that Maria Lugones develops the concept of Colonial / Modern System of Gender. She starts from Latin American and postcolonial thought criticizing the concept of development mentioned earlier, the coloniality of power, being and knowledge and also from the perception of a hegemonic feminism, which reproduces mechanisms of colonialities of power, being and knowledge among different categories of women. The author, who in 2006 joined the group Coloniality / Modernity, has found that gender was not used as an analytical category by the theories of coloniality of power, being and knowledge. For Lugones, Quijano concept of coloniality of power based upon heteronormative notions and gender biological determinism does not take into account the reality of the pre-colonial context ${ }^{10}$. As pointed out by Leticia Otero Dias (2014): “Lugones' works characterize the existing gender situation founded by modernity and are a critical epistemological construction of this situation." (Dias 2014, 3) $)^{11}$.

As pointed out by theoreticians of the Modernity / Coloniality Group, the supposed end of the colonialism period with the independence movements in several countries especially in the American continent did not actually occurred. Maria Lugones shares this idea, noting that gender presuppositions prevailing in the

10 By biological determinism we understand gender constructions determined a priori to a person biological sex. There are some strands of feminism that rely on biological determinism as a way of establishing a supposed feminine power, for example, extolling the characteristics that would be inherent to women, but which, because of patriarchy, are not valued. Other strands understand that biological sex does not determine the person gender. In gender studies, in feminist formulations and in studies on women there are many different and even contradictory definitions of gender. However, especially after Joan Scott's formulation in 1989, there is now more consensus in admitting gender as a "constitutive element of social relations based on the perceived differences between sexes, and gender is a first way of signifying power relations" (Scott 1989, 21). Gender for Lugones is clearly a social construction that establishes itself in relations of intersectionality, however, she states that these relations depend on the context and therefore adopting conceptions of these relations of a reality " $x$ " in a reality " $y$ " is to distort the reference points. Thus, preconceived notions of sex, sexuality, race, and others could not be applied in a naturalized manner in Latin America, for example.

11 Our free translation. The original follows: Os trabalhos da Lugones caracterizam a situação de gênero existente e fundada pela modernidade, e são uma construção epistemológica crítica a essa situação." (Dias 2014, 3). 
colonization event, which stressed the relations established in this period, remain practically the same in Modernity. She states that male theorists of the group were not able to problematize the categories of sex and gender in their analyses and by not doing it they reproduced the colonial thought about sex and gender based on stereotypes. Then, she observes that colonial scholars, both male and female, often mix and confuse biological sex with gender through the analysis of the work done by people of opposite sexes, reinforcing the dichotomous and binary idea of sexes. This point of view characterizes the relation that establishes that biological sex determines gender. According to Lugones, the functions performed by the people in pre-Columbian period were not determined by sex. She argues that female biological and male biological sex performed the same social functions depending on the characteristics of each person. Still for Lugones, black and indigenous people were not considered human by the settlers. This situation sets them in an almost sexual dimorphism position, like bestialized and animalistic beings. So, she states, there are no Indian and Black women, and let alone colonized women, because the woman category refers to a, white, heterosexual, European female person.

In Women, Race and Class (2016) the black American philosopher Angela Davis presents a similar argument in relation to enslaved black women and black men in the United States. According to the author, black women and men were not considered human and this justified their slavery. Black women were not considered women but a workforce and a body to be dominated and violated. Working in the same way as men, without any regalia, the question of physical strength or female incapacity so often faced by white and Western women did not apply to Black women. Thus, at the same time they were considered non-human, they also challenged male supremacy, in their equal social positioning in relation to black men. This is one of the reasons, pointed out by Davis, for the hate addressed toward black women in the United States context of 'slave-raiser'. White men felt not only in their right but in their duty to violate them, to make it clear that they were despicable beings even though they were on equal footing with black men. However, it must be said, these same white men had a sexual attachment to black women, who were considered a threat to social status by their white wives. Thus, Davis notes that, from the eighteenth to the twentieth century, in the United States, the situation of black slaves, men and women, has engendered the possibility of resistance and denial of the patriarchal system and male supremacy:

Black women suffered the same oppression as did their black companions; they were socially equal to them within the slave community; and resisted slavery with the same eagerness as they did. This was one of the great ironies of the slavery system: the cruel exploitation, without distinction of sex, has laid the foundations upon which black women would affirm their condition of equality in social relations, expressed in acts of resistance. This must have been a terrible finding for slave owners, who apparently attempted to break this condition of equality through particularly brutal repression against black women. Again, it is important to remember that the punishments inflicted on black women exceeded those imposed on black men in intensity, since these women were not only whipped and mutilated but also raped. (Davis 2016, 35-36)

Although she presents an argument similar to that of Angela Davis, concerning the non-humanity of the indigenous or black women, Lugones observes that in the Latin American case, Latin men end up "adhering" to male supremacy speech and practice brought by European white men, helping to establish patriarchy and female inferiority in this context. However, colonized men are not on equal footing with European white men. They, like black women, are considered non-humans. They are considered 
"effeminate", constituting their inferiority and the constant threat of rape (Lugones 2014, 743), suggesting that the category "woman" does not apply to such people considered nonhuman or subhuman. It is a category defined for and by a very specific model, namely: a person with a vagina and uterus, white, middle class, European female or female European descent (as in the case of Brazilian women who proudly display their Italian, German, French and other origins) who are affectively related to a man (also a white middle class, European and heterosexual), to whom she is subordinate. For her, the "civilizing mission" was a justification for the brutal exploitation of bodies:

The 'civilizing mission' used the hierarchical gender dichotomy as a judgment, thought the attainment of dichotomous gendering for the colonized into human being was not a colonial goal. The difficulty of imagining this as a goal can be appreciated clearly when one sees that this transformation of the colonized into men and male would have been transformation not in identity, but in nature. But the colonized against itself was included in the civilization mission's repertoire of justifications for abuse. Christian confession, sin and Manichean division between god and evil served to imprint female sexuality as evil, the colonized females were understood in relation to Satan, sometimes as mounted by Satan. (Lugones 2010, 745)

Lugones understands that the gender category is crucial when it comes to coloniality. For her, coloniality was established mainly by gender invention and perpetuation in colonized communities. Just like race. She postulates that colonization and Christianization are responsible for transformations beyond the control of reproductive and sexual practices. Yet, the civilizational movements of colonization transformed the relationship people had with their land and their religiosity with its symbols and signs, through the norm that links gender and civilization. For her, the imposition of the colonial system of gender leads to the coloniality of being (proposed by Nelson Maldonado Torres) necessarily inhuman. Thus, she concludes that "a colonized woman is an empty category: no women are colonized; no colonized females are woman" (Lugones 2010, 745).

With this, more than "colonized women", Maria Lugones proposes the recognition of beings that resist to the coloniality of Gender, considering the colonial difference. It is not just thinking of distant realities, such as supposedly pure indigenous communities, without contact with white people. She admits that we in Latin America are also fruit of this hegemonic thought of coloniality of power, gender, knowledge and being. We are constituted within this; however, we can assume liberating resistance postures, subjectively and intersubjectively, involving adaptation and creative opposition. And she theorizes:

Resistance is the tension between subjectification (the forming/informing of the subject) and active subjectivity, that minimal sense of agency required for the oppressing resisting relation being an active one, without appeal to the maximal sense of agency of the modem subject. (Lugones 2010, 746)

In general terms, for Lugones, active subjectivity means that there are other possibilities of categorization, living and coexistence, production of knowledge and products besides Western Europeans. These are what we commonly call "marks" of oppressed male and female. With the difference that in the case of oppressed male and female, these marks are not necessarily read as marks of oppression, but as subjectivity. It happens that many times this subjectivity of peoples, cultures and individuals are simply 
impossible to be grasped by dominating groups, which leads to systemic silencing and oppression. However, for Lugones there is no pure race. That is, there is no race which has not suffered colonization consequences and has not integrated colonizing and modern values and practices. These cultures, people and persons are in a third place, in-between, at the border. As Gloria Anzaldúa remarks this is related to the mestizo conscience, which is, according to her, characterized as the one between places, like the border between western white man or western white woman and indigenous man or indigenous woman, Latin man or Latin woman and black man or black woman. She rightly proposes the possibility of being and remaining on the border:

From this racial, ideological, cultural and biological "transpolinization" emerges another consciousness - a new mestizo consciousness, a woman consciousness. An awareness of the Frontiers (...) These innumerable possibilities leave la mestiza drifting in unknown seas. By perceiving conflicting information and viewpoints, she immerses herself in her psychological boundaries. She finds out that she cannot keep concepts or ideas within rigid limits. Boundaries and walls that must hold undesirable ideas outside are entrenched habits and patterns of behavior; these habits and patterns are the internal enemies. Rigidity means death. Only by remaining flexible can she extend the psyche horizontally and vertically. La mestiza has to constantly move out of the crystallized formations - of habit; out of convergent thinking, from analytic reasoning that tends to use rationality toward a single goal (a Western way), towards a divergent thinking (Anzaldúa 2005, 704).

Through Gloria Anzaldúa's comments we can see that this inter-place, being at the border, incorporates the contradictions that permeate our lives and allow us to have another look on the oppression marks of the groups considered subalterns, seeing these marks as strong, beautiful, powerful, inspiring, creative, and resilient. This is Maria Lugones proposal:

My intent is to focus on the subjective-intersubjective springs of colonized women's agency. I call the analysis of racialized, capitalist, gender oppression "the coloniality of gender". I call the possibility of overcoming the coloniality of gender 'decolonial feminism' (Lugones 2010, 747)

Therefore, the question is to identify mechanisms and processes of gender coloniality (which encompasses that of power, being and knowledge and are also part of them) that establish ways of life, coexistence, knowledge production that silence not hegemonic knowledge and practices. Having identified coloniality mechanisms and processes, it is possible to understand where and how forms of resistance occur. In order to know how these theories applies to nowadays reality, we propose to see some forms of resistance in two specific music initiatives in Brazil.

\section{Two examples of feminist and decolonial resistance initiatives in Brazil}

Before presenting these two initiatives, we consider it to be important to clarify that the choice of these two examples is not based on merit alone. We understand that in both examples that we bring to analysis represent possibilities of resistance, within which Maria Lugones conceptualizes as decolonial feminism, however we do not consider these examples more important or better than others that also exist. This is 
important in order not to fall into the current practice of a certain historical tradition responsible for the constitution of canons in the History of Humanity ${ }^{12}$. It is precisely this posture, of choice and election of a unique model that leads to Canons formation which, necessarily, operate with silencing and rendering invisible of the non-hegemonic. That said, we understand that the examples we present here were chosen from our experiences and affectivities and have the power to be thought as possibilities of decolonial feminism, setting up places and practices of rupture and creative proposition.

In Brazil, we are experiencing an intense blossoming of women in experimental music. Through appropriation of technology, collective creation and networking, learning new possibilities in music and conviviality that are not common in our traditional institutions of teaching, production and placement of music. The examples we highlight, therefore, are two of many. We understand that both represent possibilities of resistance, however we recognize the limitations when thinking about these examples in a wider Brazilian context.

The first example is the Mostra XX - XX Show. Broadly speaking, the show is an event that brings together musical and artistic production performed only by women. In the Facebook page of the show held in São Paulo in 2015 the shared text was as follows:

$\mathrm{XX}$ is a show that aims to provide the meeting between women creators and give vent to the artistic production that emerges from this confluence. There will be musical works transiting between experimental, sound and visual art, photography, improvisation and performance (Ibrasotope 2015).

Three editions of the show were held, two in California (2014, and 2017) and one in São Paulo, in 2015. At the head of these editions was Fernanda Aoki Navarro, a Brazilian composer, a Latin-American woman with Japanese ancestry. These social marks locate her among women of color $^{13}$, a racialized and ethnicized human group both in the north-American and the Brazilian contexts. The first edition held in the United States was incorporated in the Spring Festival in The University of California - San Diego (UCSD). The show was thought as a response to a sexist speech from an important conductor, in which he suggests women are not as capable as men of maintaining a conducting career because of physiological issues supposedly

12 "Canon" has already been theorized by numerous researchers in several areas. We bring in the scope of this article the concept developed within the context of the History of Western Music. According to Marcia J. Citron, in Gender and Musical Canon (1993), one of the first people to problematize canon in music was Joseph Kerman in A Few Canonic Variations (1993). Based on Kerman and even more in feminist studies and theories and critics, Citron drew up her own perceptions of Canon and states that the constitution of a canon is responsible, for example, for the female miss representativeness in music. For Citron, canon, identified by her as something that "deserves" being used as a reference of a given culture: "what is worthy of inclusion" (Citron 1993, 15) and is determined by this same culture. That is, culture, through social practices and rules of teaching, training and production of knowledge establishes criteria used to consecrate a given production which in turn is the product of these same criteria. Thus, women are excluded, literally from the Western classical music canon because the production of this song is based on criteria that do not allow or facilitate female participation. We do not have to go to great lengths to realize that this situation only worsens when we think of nonwhite, non-Western, non-European and other women.

${ }^{13}$ Here we understand women of color as proposed and thought by Cherríe Moraga and Gloria E. Anzaldúa in the book This Bridge Called My Back: Writings by Radical Women of Color (1981). 
biologically inherent in women's bodies. It is interesting to note that the first event, held in 2014, was a response to a male discourse in an attempt to "show the world that women can do whatever they want, including a concert entirely produced by women with women" (Navarro 2015) ${ }^{14}$. The second event in California (2017) arose in a more purposeful than reactive way, being a tribute to Pauline Oliveros. In the program the composers put themselves as a feminist collective and explain the title "XX", which even alluding to the chromosomes that "determine" the female sex, does not refer to the "woman bound to a biological determinism", but to people who are identified in this gender. In the program of Show XX 2017, the collective assumes the mantle of intersectional feminism. It is symptomatic that Fernanda Aoki Navarro, a Brazilian and Latin-American woman, with Asian Japanese ancestry, takes the lead in this intersectional and feminist movement, in convergence with that of the decolonial feminisms and also the Asian feminisms ${ }^{15}$. Though the fact of being Brazilian does not necessarily make her position and presence non-hegemonic, and it is possible to perceive some tension regarding the curricula and canons in the text of the program itself.

Fernanda Aoki has led the Show XX in Brazil in partnership with the artists Natacha Maurer and Renata Roman. The event was attended by the following artists: Bella, Denise Garcia, Fernanda Aoki Navarro, Jiulian Gonçalves, Flora Houlderbaum, Natacha Maurer, Renata Roman, Marcela Lucatelli, Sanannda Acácia and Vanessa de Michelis. In São Paulo context, the event may be considered a milestone for a number of reasons.

To understand the impact that the show had, it is important to say that São Paulo, being the city with the greatest economic and cultural power in the country, is often considered the greatest reference in many cultural fields in Brazil. This condition is responsible for the Brazilian imaginary in which São Paulo is the cradle of innovations in Brazil and at the same time other localities are marginal and do not establish themselves as reference or viable models. In this way is configured Internal Colonialism, proposed by Walter Mignolo. Often what prevails, contrary to what one might imagine, is not necessarily what differs, but what reaffirms power positions.

Also, it should be said that the female presence in the scene, although much more representative than other fields of creation in music, is still quite a minority. The city's main experimental music production and promotion venues are mostly male: man-run, with performances by men and frequented by men. It is in this context that the XX Show establishes itself as a milestone that weakens the relations of internal colonialism which are within the colonialism of gender, as Maria Lugones puts it.

When performing an experimental music event all run by women, without an aesthetic pre-establishment, assuming improvisation at various levels, with women from other locations besides São Paulo, the XX Show can break with some production logics with very strong roots in the City and also in the country.

Thus, amongst other things, it:

\footnotetext{
14 This was a statement by Fernanda Aoky Navarro about the XX SHow in an interview with Tânia Mello Neiva on 3/08/2015. Navarro was one of the composers who organized de show in the three editions.

15 As pointed by Sonia Sha in Dragon Ladies: Asian American Feminists Breathe Fire (1999); Chandra Talpade Mohanty in Feminism without Borders: Decolonizing Theory, Practicing Solidarity (2003); Linda Trinh Vo and Marian Sciachitano in Asian American Women: The Frontiers Reader (2003); Lora Jo Foo in Asian American Women: Issues, Concerns, and Responsive Human and Civil Rights Advocacy (2002).
} 
- Launches seeds for the formation of initiatives for the production of women's experimental music in the city of São Paulo, like the project Dissonantes, by Renata Roman and Natacha Maurer (which disseminates experimental music in São Paulo made by women) a direct result of the Show;

- Provides greater visibility to the issue of women in experimental music in the local context;

- Groups together women from different locations across Brazil within the same event.

Although this show has happened only once in Brazil, women who took part in it made and are part of networks that move important experimental music spaces in the country, and especially in São Paulo. It is worth saying that it is very difficult to say everything about a country of continental proportions such as Brazil. So, it is not our intention to be exhaustive, instead we will be happy to address some points for a possible reflection on the field. Of the women who participated in Show XX, Sanannda Acácia (who is from Curitiba, the capital of Paraná State) is one of the leaders of Seminal Records label ${ }^{16}$, Bella (from Rio de Janeiro) participates in collective Meteoro and develops a solo work, with creations, performances and workshops; Renata Roman and Natacha Maurer (both from São Paulo State, Roman is from the capital and Maurer from the interior) organize the Dissonantes project, which promotes women experimental music concerts as already mentioned. Van de Michelis (from Belo Horizonte, the capital of Minas Gerais State) provides do-it-yourself technology workshops geared specifically for women and specifically for lesbian women. Jiulian Golçalves (from São Paulo) is mostly involved with the queer and feminist punk scene in the city. Flora Houlderbaun (from Florianópolis, the capital of Santa Catarina State) is one of the current editors of Linda ${ }^{17}$, an electronic magazine on electroacoustic and experimental culture. Denise Garcia (from São Paulo) is a music composition teacher at a prestigious University in the country, UNICAMP. Marcela Lucatelli (from São Paulo) has been living in Germany to continue her music composition studies and has been involved with different kinds of experimental music events in Brazil and abroad. All these projects, labels, collectives and initiatives collaborate to the visibilization of women's work at the experimental music field in the country. It is important to note that all these artists were "located" or "situated", more or less, in the artistic scenes of São Paulo when the event happened. We observe that, even though they have different geographic origins, their articulations and activities in the artistic fields of São Paulo were important aspects for their participation and presence in the "XX Show". This indicates the centrality of the city also in the internal colonialities of knowledge, power and knowledge in the country itself, also in the artistic fields.

Perhaps the most important mark of breaking with or weakening the hegemonic logics of musical production in São Paulo city and in Brazil was precisely the collectivity in the event production and the fact that it was performed by Brazilian women. It must be said, however, that most of these Brazilian women are white, or at least, not black women, reproducing other kinds (race) of hegemonic representativeness inside this field. Also, even though most of them are not from São Paulo, by the period the XX Show was taken, all of the artists had an insertion in the scene in São Paulo, which means that we cannot read them as completely away from the power structures that are reproduced in the city because of what the city represents in a wider Brazilian context. In other words, a way, these artists are also part of this dominant scene of São Paulo, even being from other places. The composers not only played their pieces but also built this space where there was no aesthetic or technique curatorship. It means that even if the organizers (Fernanda Aoky Navarro, Natacha Maurer and Renata Roman) had a plan and invited specific women to

\footnotetext{
${ }^{16}$ See: https://seminalrecords.bandcamp.com/

17 See: http://linda.nmelindo.com/
} 
compose the event (which could be interpreted as a kind of curatorship), they did not tell them what they were or what they were not supposed to do or to play. The eventual restriction was related mostly to technical limitations, for example of instruments, or specific technology. The set was stereo with two Power Amplifiers (PA), for example, instead of a more complex system (four PAs). The capacity to do what they wanted, so rare in the world of traditional music, was further reinforced by the feminist understanding that freedom was also a form of expression of voices that had much to say although little heard.

Thus, we can say that both in the aesthetic aspect - by the very characteristic of experimentalism that corrupts hard and fixed norms, which distorts notions of beauty, noise and musical - as by the very dynamics of the show production - which had the collaborative involvement of women, each one bringing her expertise to compose the whole in solidarity without necessarily establishing hierarchical relationship between them, the exhibition in the context of São Paulo can be read, in a specific context, as a nonhegemonic possibility of production, because it was:

1. Made totally by women (Brazilian) from the experimental field in music; demonstrating that there are women involved with experimental music and that they can do an event by their own. This confronts the way things usually happen in this field because of male dominance, both concerning the artists, as the public;

2. It was constituted by women from different places of Brazil;

3. It had no aesthetic curatorship (at least not direct), which also confronts the usual idea of quality and control, characteristics that are usually valorized in the musical universe. By not establishing a direct curatorship, the organizers take the risk which can result in new approaches and propositions with sounds and music.

The second initiative that we address in the scope of this speech is the duo formed by the artists / composers / performers Isabel Nogueira and Leandra Lambert.

Isabel Nogueira is an artist, songwriter, performer, singer-songwriter, university teacher, mother, feminist and many other things. Throughout her musical trajectory the artist was perceiving herself outside standards and norms of diverse forms. She was told she had no voice, her compositions had no metrics and the melodies did not close, according to a conception of voice and composition strictly based on singing techniques and musical writing of Western European tradition. This tradition, which has been built for the last three centuries, at least, is based, mainly on the paradigm of the scripture in music in which the complex of counterpoint, development and maximum control of the parameters such as "tune", "rhythm", "harmony", "timbre" are valued. Throughout the development of the musical writing in the Western Culture it was possible to make more and more complex music. At the same time the ideal musical sound (of voice, or any other instruments) were rising as well, electing some "genius" performers, that in the 20th century with the invention of the recording could be eternized as a reference of "a good sound". Therefore, the singing (or the playing of any other instrument) in Western traditional music had and has a very specific aim and model. So has the writing which is supposed to guarantee the "truth" in music (Adorno 1982; Goehr 1989, 85), preceding the necessity of a relationship between composers and performers, especially from the 18th century beyond (Goehr 1989, 56).

Throughout her career, Isabel Nogueira was aware of the impositions she was subjected to in the field of formal Western European erudite music, which necessarily made it impossible for her to speak what she 
wanted, to express herself as she wanted, to be who she was. To reach the expectations of what is considered a good musician in this tradition it is necessary to adapt the body and, sometimes, the beliefs. It means that usually we are not encouraged to know or question about in what context the music was written and for what purpose, in a belief of a supposed autonomy of music considering these things as "extra musical". The way of playing, singing and composing are very specific in this tradition, so, if a person does not fit well in this specificity, she or he is not considered a good musician. Isabel was told, for example, in her early years of learning that she "moved too much to play the piano" and that she "questioned too much to be a pianist" (Nogueira 2017) ${ }^{18}$.

Like Nogueira, Leandra Lambert is also a multi-artist, producing visual arts, literature, music, sound art, cinema and others activities. She has no formal training in music and since the 1990s she has started to make electronic / experimental music. Leandra is multiple. Her interest and acting in various arts can demonstrate, like Isabel, a possibility of non-framing in any field defined a priori and at the same time the possibility of existence in between-places.

Isabel Nogueira and Leandra Lambert duo appeared as a duo in the fifth edition of the Dissonantes project, in July 2016. An important consideration in relation to the duo is the way both artists work. Each one lives in different states, and it is not possible to have frequent face-to-face meetings and rehearsals. Thus, they have established some main forms of work. This took the form of the following:

- They exchange ideas through internet and each one produces sounds and projects individually which are then shared and reworked, the final compositional work being with sufficient editing and interference from both artists;

- Each one individually produces the sound proposals and pieces of music which are overlapped partially at random. The final work is, therefore, a collage of overlaps whose result cannot be predetermined;

- They determine a script with some definitions of sounds and textures and sound "climates" and improvise in person from these predetermined scripts.

Thinking about traditional practices of musical composition (both written and electroacoustic), which presupposes planning and the maximum possible control of the constituent parameters of the piece, the methodologies used by the composers can be understood as transgressors, since there is no Maximum control of the chosen parameters. This occurs by assuming "chance" as aesthetic component. Even though these techniques are not new, thinking, for example, of Cage who used chance to compose, their use is still taboo in the more traditional mediums of music, at least in Brazil. In addition, the possibility of composing in a distance partnership, a resource increasingly used from the evolution of the internet, also demystifies the very design of face-to-face rehearsals and, again, enables maximum control of the variables, since in this process distance is admitted as Creator component that establishes other criteria of time and relationship between those involved. The technique of collage is also not new, however, it is also considered, within the hierarchies of compositional practices, a less prestigious technique, as opposed to the idea of development. Thus, the collage technique is seen as smaller, simpler, less important. By reformulating non-hegemonic possibilities, we might think that using resources considered marginal, such as "collage" and chance, for example, is to assume that the marginal can be seen as force, beauty and power, opposing the idea of a single possibility, which would be, in this case, development and control. This brings

18 In an interview with Tânia Neiva, 20th of March, 2017. 
us back to the idea that, instead of the marks that characterize the marginal as marks of "subalternity", we can see them as marks of "overcoming, creativity, identity", and so on. When the dark color of the skin or the "south" place of origin of a person, the "non-christian" religion and the "non-white" cultural values are seen as different, or less important or as marks of subalternity comparing to the light color of the skin, the north place of origin, the christian religion and white cultural values, it is established an hierarchy, in which the white, north and christian are recognized as better, as prettier and so on. To choose to see these supposed marks as subalternity, is to assume, in Lugone's view, the "white", "north" and "christian" as the reference. So, Lugones proposes that instead of admitting these marks as subalternities we choose to see them as strength and "overcoming identities". We suggest that the "collage" and the "chance" in Nogueira and Lambert's music, in a hegemonic view, would been seen as "marks of subalternity", but if we assume a political view, like Lugones proposes thinking about peoples, these marks can be seen, as an analogy, as "overcoming, creativity and identity" in a positive way.

Thus, with the sum of all these compositional methodological techniques used by the artists, we can say that both, in a way, break solid schemas associated with musical composition by proposing other ways of music creation, translated into less rigid and more fluid ways which are less committed to a tradition. By questioning these traditional methods and techniques they are, actually, questioning mechanisms of power in music, that has been legitimating the figure of the composer (male, white, heterosexual and Western European as pointed by authors like Lucy Green, 2001 and Pirkko Moisala, 2015), and the supremacy of written music. Power, in this sense could be understood, also, as a characteristic of a patriarchal thought, in which all that is related to man and to masculine is seen as in a higher level of a hierarchy, opposing to all that is related to woman and to feminine. Since composition has been, during the development of Western Music, associated with rationality opposing to emotion, for example, the association with the male dominance was immediate. Man, and masculine has been associated to rationality, culture, rightness and so on and women and feminine to all that is opposite to man and masculine (Bourdieu 2003; Grosz 2000; Ortner 1979). When the artists propose methods and techniques that, in a way, deny the things that are valorized in a tradition of the composition area, they are denying these mechanisms that affirm the hierarchy of things considered masculine.

At the same time, we could say that creative sound practice is linked to feminist epistemologies when it brings women to the center of the scene and makes them protagonists of the processes at all levels, while being built on dialogue and making empowering for all.

In addition to the methodology of work and composition the content that both artists explore is also quite significant within a logic of rupture. They essentially work with voice and technology. Before presenting their uses in the duo's works it is important to address the symbolic relevance of the voice in women's works. According to Cathy Lane (2016) and Janete El Haouli (2002) as a social, cultural and historical construction, the voice, within the field of emotions, also allows us to perceive the power apparatuses that are constructed, reinforced and reproduced through it (the voice). This brings us, again, to the issue, already discussed, of how women are silenced. When feminist movements speak of silence and invisibility, they refer precisely to the idea that the voices and bodies of women do not deserve and cannot have a place of prominence, power, or even autonomy.

In the works of Isabel Nogueira and Leandra Lambert the voice is used in several ways, including:

- In melodic vocalizations referring to shamanic and / or ritualistic songs; 
- It is used with a semantic sense, exploring texts whose meanings are important for apprehension of the piece. In most cases the texts refer to the feminine universe, feminist questions, or question, satire and criticize hegemonic cultures, as is the case of Encarnando Umas Vozes, in which the artists recite a text of a woman character that talks about her universe. In the text the woman talks about how her references in music and in life as general were built on a male basis and how she managed to deconstruct and confront these references. She asks herself what is to be a woman and the response is, at the same time, very affirmative and feminist when she says, for example: "My father and my stepfather, my grandfather, my teachers all and other figures of authority hadn't the pretension of saying what I should or should not hear and if they did it they would hear a 'fuck you'. Some boyfriends had the arrogance to pretend to know what the best was, but they stayed there with their annoyances and I listened to what I wanted." ${ }^{19}$ And reaffirms some stereotyped vision of femininity when they use, in the back sound, a female shamanic singing which operates in a proposition of valuing these stereotyped visions.

- It is used as a dissociated object of referentiality, exploring the possibilities of sound / noise of the voice. The voice in this piece mentioned above, is used with this semantic sense with a text that is recited and has the intention to be understood and, also, with the exploration of sounds of phonemes, without a semantic sense, like "sssss", "tztztz", "rrrrr", or sound of breathing, groan, sigh and others.

Thinking about the symbolic issue of the use of the voice by women, when Isabel and Leandra use their voices in their work, they break with a supposed silence that is demanded of women, and, at the same time, reaffirm women's places of power. When referring to shamanic or ritualistic songs, Leandra and Isabel refer to women from cultures in which the singing of women means power and strength. These cultures and these women have been subject of interest of some feminist ethnomusicologists such as Carol E. Robertson (1993) and by the decolonial feminism thinkers. Robertson (1993), for example, studies the Mapuche people in Argentina and the shaman function in that society. As she points out this function, called machi is ${ }^{20}$ usually practiced by the women of the group and they are recognized as:

powerful spiritually in that they were able to harness the transformational forces of female energy. Their clairvoyance made them extremely powerful politically as well: in their ability to see the many layers of the present, they were often able to move their people to action. Their ability to predict hostile attacks, their power to mold public opinion and their ability to strengthen defeated warriors through chant made the machi a serious threat to the Argentine military. (Robertson 1993, 109-111. Emphasis added).

Gloria Anzaldúa highlights the importance of the spiritual dimension that connects "the different worlds" (material and spiritual) in the identity of the people from colonized places that were violated from their

19 This is a part of the text recited by Isabel Nogueira in the piece Encarnando Umas Vozes by Isabel Nogueira and Leandra Lambert. This is a free translation. The original text is: "Meu pai e meu padrasto, meu avô, meus professores todos e outras figuras de autoridade não tiveram a pretensão de dizer o que eu devia ou não ouvir e se tivessem iam ouvir um "vão se fuder". Alguns namorados tiveram a arrogância de pretender saber o que era o melhor, mas ficaram lá com suas chatices e eu ouvia o que queria".

${ }^{20}$ It is important to say that there was a genocide of the Mapuche people in Argentina in the 19th century. Today, early 21st century, there are still some Mapuche people in Argentina and in Chile. They are struggling to have a territory of their own and to maintain their traditional culture. 
(ours) history and ancestry. She suggests that the feminism in this reality must consider these things that made and make the history of "our" people strong and genuine:

There are certain traditions like the shamanic tradition that teach you to experience the interpenetration of those other worlds. (...) So here we go as feminists-wanting to be practical, wanting to make a difference, wanting to make some changes. We're looking at everything that gives us strength: having roots, having a historical past that we can connect with and say, "This is the route that my particular group has walked and I can see how what happened in the past has affected the present and therefore affected me and who I am and how I feel about myself". So we've dug into the past for a history and models and women and stories that can give us some sort of ground to walk on, some sort of foundation, some sort of place to take off from and also to find positive stuff there that will feed us, that will inspire us. (Anzaldúa 2000, 159-160)

Therefore, by singing referring to shamanic and ritualistic chants, in a female voice, Isabel Nogueira and Leandra Lambert brings the reference of women that were recognized as powerful and strong in their societies. Women that had an important social role to play, confronting our patriarchal culture in which these values (those referred to spirituality and femininity) are neglected and devaluated.

By using feminist texts from the feminine universe and / or questioning, satirizing and criticizing hegemonic models and practices, the two artists are refusing to be silent, even and especially in the face of oppression. If, on the one hand, the field of experimental music is more open and free to experiment, on the other hand it is still male domain, so bringing explicit texts that present the feminine universe and feminist questions transgress and propose a political action through music. The use of voice noise refers to a more explored place within the field of experimental music, which breaks away from the notion of musical sound of a certain traditional musical culture (lazzetta, 2014; Campesato 2013).

Still, the two artists use technology to record, edit, distort, and interfere with their music. In general, the use of technology by women in itself is already a transgressor, since technology is generally associated with men and masculinity, as pointed by many authors such as Georgina Born (2015), Tara Rodgers (2010); Andra McCartney (1997), Pirkko Moisala (2000) and Lucy Green (2001).

Finally, we would like to reiterate that the intention of this presentation is not to speak on behalf of any specific group. We propose a reflexive and critical look at our local context and possible creative and political outings of the traps that are imposed on us and that we also help to arm.

Living and creating borders, for us, is that. To realize the oppressions and privileges we suffer and enjoy. It is to risk an analysis with a huge desire for social changes and effective improvements to the lives of the most oppressed people in the world. It is not having answers but proposing ways and reflections.

\section{References}

Adorno, Theodor W. and Max Paddison. 1982. "On The Problem Of Musical Analysis". Music Analysis 1 (2): 169-187.

Anzaldúa, Glória. 2005. La consciência de la mestiza/rumo a uma nova consciência. Estudos Feministas 13 (3): 320. 
Anzaldúa, Glória. 2000. Gloria E. Anzaldúa Interviews. Edited by Ana Louise Keating, New York: Routledge.

Ballestrin, Luciana. 2013. América Latina e o Giro Decolonial; Revista Brasileira de Ciência Política 11, 89117.

Barbosa, Regiane R. and Techela F. Maso. 2014. Possíveis Contribuições De Aníbal Quijano Para As Relações Internacionais. In ENEPEX - encontro de ensino, pesquisa e extensão, $8^{\circ}$ ENEPE. Available at: http://eventos. ufgd. edu. br/enepex/anais/arquivos/435. pdf

Born, Georgina. 2015. "Music Technology, Gender, and Class: Digitization, Educational and Social". In Twentieth-Century Music 12/2, 135-172. Cambridge: Cambridge University Press.

Bourdieu, Pierre. 2003. A Dominação Masculina. Translated by Maria Helena Kühner. Rio de Janeiro: Bertrand Brasil.

Campesato, Lilian. 2013. "Limite da Música Ruído: musicalidade, dor e experimentalismo". Paper presented at the XXIII Congress of the Associação Nacional de Pesquisa e Pós-Graduação em Música ANPPOM, Natal/RN, August 1-9.

Citron, Marcia. 1993. Gender and the field of Musicology. Current Musicology 53: 66-75.

Davis, Angela. 2016. Mulheres, Raça e Classe. Translated by Heci Regina Candiani. São Paulo: Boitempo.

Dias, Letícia Otero. 2014. O Feminismo Decolonial de Maria Lugones. In ENEPEX - encontro de pesquisa, ensino e extensão. $8^{\circ}$ ENEPE UFGD, $5^{\circ}$ EPEX UEMS. Available at: http://eventos. ufgd. edu. br/enepex/anais/arquivos/318. pdf.

El Haouli, Janete. 2002. Demetrio Stratos: em busca da voz-música. Londrina PR.

Foo, Lora Jo. 2000. Asian American Women: Issues, Concerns, and Responsive Human and Civil Rights Advocacy. Universe Inc.

Goehr, Lydia. Winter, 1989. Being True to the Work, The Journal of Aesthetics and Art Criticism 47 (1): 5567. Available at: http://www. jstor. org/stable/431993. Accessed em: 29/01/2015.

Green, Lucy. 2001. Música, Gênero y Education. Translated by Pablo Manzano. Madrid: Morata, 2001.

Grosz, Elizabeth. 2000. Corpos Reconfigurados. Cadernos Pagu. Campinas 14: 46-86.

Hurtado, Liliana. 2016. Los Teoricos del Análisis del Sistema Mundo; Available at http://www. unsa. edu. ar/historicat/historiahoy/cart-hurtado. htm.

lazzetta, Fernando. 2014. "Entre a pesquisa e a criação: a experiência dentro da sonologia". Paper presented at the XXIV Congress of the Associação Nacional de Pesquisa e Pós-Graduação em Música ANPPOM, São Paulo, August 1-9. Avaliable at: http://www2. eca. usp. br/prof/iazzetta/papers/anpp om 2014 iazzetta. pdf.

IBRASOTOPE. 2015. Mostra XX 2015. Avaliable at: http://www. ibrasotope. com. br/2015/08/ibe50-xx. $\underline{\mathrm{html}}$

Lane, Cathy. 2016. Why not our voices? In: Women and music: a Journal of Gender and Culture 20: 96-110.

Lang, Mirian. 2016. "Alternativas ao Desenvolvimento". In Descolonizar o Imaginário - debates sobre pósextrativismo e alternativas ao desenvolvimento, edited by Gerhard Dilger, Mirian Land and Jorge Pereira Filho, São Paulo: Fundação Rosa Luxemburgo. 
Lugones, Maria. 2010. "Toward a decolonial Feminism". Hypatia 25 (4). Available at: www. iheal. univparis3. fr/sites/www. iheal. univparis3. fr/files/towards\%20a\%20decolonial\%20feminism. pdf

Maldonado-Torres, Nelson. 2016. Transdisciplinaridade e Decoloniadade. Translated by Joaze BernardinoCosta. Revista Sociedade e Estado 31 (1).

Mariz, Renata. 2013. País tem 705 mil mestres e doutores. In: Em. com. br Educação. Available at: http://www.em.com.br/app/noticia/especiais/educacao/2013/04/23/internas educacao,375760/pais -tem-705-mil-mestres-e-doutores. shtml

McCartney, Andra. 1997. Creating Worlds for my Music to Exist: How Women Composers of Electroacoustic Music make Place for Their Voices. Master of Arts thesis. York University, North York, Ontario.

Mena, Ana Marcela Montanaro. 2016. "Herencias genealógicas del feminismo decolonial en América Latina: Hacia la construcción de un Tercer Feminismo". Master diss. Instituto de Derechos Humanos "Bartolomé de las Casas" Curso académico.

Mohanty, Chandra Talpade. 1984. "Under Western Eyes: Feminist Scholarship and Colonial Discourses". Boundary 212 (3), On Humanism and the University I: The Discourse of Humanism: 333-358.

Mohanty, Chandra Talpade. 2003. Feminism without Borders: Decolonizing Theory, Practicing Solidarity. Duke University Press.

Moisala, Pirkko. 2015. "A Negociação de Gênero da compositora Kaija Saariaho na Finlândia: a Mulher Compositora como Sujeito Nômade". Translated by Camila Durães Zerbinatti. Revista Vórtex, Curitiba $3(2): 124$.

OECD 2015 (2015) - Brasil - Country Note - Education at a Glance 2015: OECD Indicators. Available at: https://www.oecd.org/brazil/Education-at-a-glance-2015-Brazil-in-Portuguese.pdf

Ortner, Sherry B. 1979. "Está a mulher para o homem assim como a natureza para a cultura?". In A mulher, a cultura, a sociedade, edited by Michelle Zimbalist Rosaldo and Louise Lamphere, 95-120. Rio de Janeiro: Paz e Terra.

Quijano, Aníbal. 2005. "Colonialidade do poder, eurocentrismo e América Latina." In Colonialidade de Saber: Eurocentrismo e Ciências Sociais. Perspectivas Latino-americanas, edited by Edgardo Lander, 107-130. Colección Sur Sur, CLACSO, Ciudad Auntónoma de Buenos Aires, Argentina.

Robertson, Carol E. 1993. "The Ethnomusicologist as Midwife". In Musicology and Difference - Gender and Sexuality in Music Scholarship, edited by Ruth A. Solie, 107-124. Berkeley: University of California Press.

Rodgers, Tara. 2010. Pink Noises: women on electronic music and sound. Durham: Duke University Press.

Santos, Boaventura de Sousa. 2009. "Para além do Pensamento Abissal: das linhas globais a uma ecologia de saberes". In Epistemologias do Sul, edited by Boaventura de Souza Santos and Maria Paula Meneses, 23-73. Coimbra: Edições Almedina.

Scott, Joan. 1989. Gênero: uma categoria útil para análise histórica. Translated by Christine Rafino Dabat, and Maria Betânia Ávila. New York: Columbia University Press.

Sha, Sonia. 1997-1999. Dragon Ladies: Asian American Feminists Breathe Fire. South End Press.

Swain, Tânia Navarro. 1996. "A construção imaginária da história e dos gêneros: O Brasil no século XVI". In: Textos de História 4 (2). Available at: http://periodicos.unb.br/index.php/textos/article/view/5789/0 